\title{
An Investigation into Rural School Parent Governors' Understanding of the Legislations that Impact on School Governance
}

\author{
M A N Duma \\ University of Zululand, South Africa
}

\begin{abstract}
The aim of this article is to investigate the rural school parent governors' understanding of the legislations and policies that impact on the school governance. An argument is presented that the understanding of the legal frameworks pertaining to school governance begins with the parent governors' understanding of the education legislations. The article reports on a study in which quantitative methodology was used to obtain information from rural school parent governors about their understanding of certain sections of the education legislations and policies that have a founding impact on school governance. The study is concluded by the submission that it is essential for rural school parent governors to be given necessary training so that they can have a working knowledge of the legislations that impact on school governance so as to understand the legal processes and principles and determine the legality of their decisions.
\end{abstract}

\section{Introduction}

Many states have established laws that govern education to include the parent component in the governance of schools [6], [28]. The parent component in school governance is designed to bring about the democratization of education, which encompasses the idea that parents, as one of major stakeholders in schools, should be able to participate in the governance of the schools, which can be realized by the establishment of school governing bodies in which ". . . the number of parents must comprise one more than the total of other members of a governing body who have voting rights” [30]. In 1996, the South African government introduced several reforms in the form of education policies and legislations intended to democratize education and school governance. The most comprehensive of these reforms are catered for in the South African Constitution Act (Act No
108 of 1996) and in the South African Schools Act (Act No 84 of 1996). Since the establishment of these Acts, the enormous expectations imposed on parent governors have prompted a significant change in the nature and scale of their accountability [3].

The fragmentation of the old South African education system along racial lines, entrenched the manner in which parent governors' involvement in school governance existed. Under the apartheid regime, the participation of parents in school governance was limited and exclusive. The role of parents was limited to that of backbenchers and fundraisers only. Furthermore, parent governors were often appointed rather than elected. The present situation demands that all schools including rural schools must have democratically elected parent governors [30]. In this instance, parents, who previously had no legal authority on issues of school governance, are now legally required to be involved in the governance activities of schools. This involves policy-making, coordinating, controlling, and evaluation [3] - duties that require competent and motivated parent governors.

Taking into account the high rate of illiteracy and semi-literacy in rural school areas, this article aims to investigate the rural school parent governors' understanding of the legislations and policies that impact on school governance.

The concept of education law is novel to many rural school parent governors and this lack of preparation makes the task of legal intervention foreign and uncomfortable to most rural school parent governors. Serious offences such as sexual harassment, unfair discrimination, corporal punishment, and other criminal activities committed in schools both by learners and educators are on record. With the upsurge of these acts, the demand for school - based legal intervention services in rural schools has increased significantly. There is ample evidence that rural schools are not immune to violence. Escalating crimes varying from relatively less serious incidents, such as fistfights, theft, or vandalism, to 
serious crimes such as a rape, physical attacks with weapons or robbery occur in rural schools and parent governors are expected to make decisions which warrant the understanding of the legal principles and processes. It should be noted that no particular attention to the training of rural school parent governors in the education legislations is evident.

It is, therefore, ironic that rural school parent governors with no proper training in the education legislations are expected to deal with legal challenging circumstances. Training programs for rural school parent governors in school governance will not only equip them with the tools they require for effective school governance obligations, but will also promote their status as effective school governors. Well-trained parent governors in school governance, will, in times of needs, make quick, accurate, and critical decisions. Consequently, the training of rural school parent governors in the legislations that impact on school governance practice such as the Bill of Rights and the South African Schools Act will provide for more potent and constructive parent governors.

This article reports on a study in which quantitative methodology was used to obtain information from rural school parent governors about their understanding of the legislations that have a founding impact on school governance such as the Bill of Rights and the South African Schools Act. Consequently, the purpose of this article is to draw attention to issues such as the essentiality of the rural school parent governors' working knowledge of the legislations that impact on the school governance, the rural school parent governors' knowledge of the sections of the Bill of rights and the South African Schools Act and suggestions by the rural school parent governors that can improve their understanding of these legislations.

First, the background to the study is provided, next, an overview of parent governors' involvement in school governance and the genesis and the substance of the Bill of Rights and the Schools Act are presented and the method of investigation and results are discussed. Finally, the implications of the findings are outlined.

\section{Research Background}

There are literally hundreds of books, journal articles, and stand-alone reports on the subject of parent involvement in education. These writings include research reports, expert opinions, theory papers, program descriptions, and so forth [11], [17], [23]. However, a cross-section of the field of education management reveals that very little research has been conducted on the rural school parent governors' understanding of the legislations that impact on school governance. The understanding of these legislations by the rural school parent governors is instrumental in ordering the rights and the duties of all parties involved in schools so that there is a harmonious and balanced order between all the school participants [26]. A cross-section of the field of education management reveals that very little research has been conducted on rural schools with regard to the rural school parent governors' understanding of legislations and policies that impact on school governance. Scientific studies on this research problem are not yet available. The dearth of literature on this research problem is itself an indication that research has to be done in order to provide more insight and improved approaches to this issue. This study seeks to fill this gap, and it is in this regard that the current research is deemed as an exploratory enterprise in South Africa specifically, and in the whole world generally. It is hoped that this study will make a great contribution to the improvement of school governance in rural schools.

The research studies have revealed that many governments have recognised the need for legislations to ensure that parents are intensively involved in school governance. This recognition is based on the realization that parents have a right to play an active role in their children's education, and that parent governors may help alleviate some of the problems faced by learners [23]. As Macbeth [21] and Postma [27] have observed, parents are first-line clients of the school and should be drawn into school activities not only in terms of auxiliary tasks, but also in the school governance functions such as planning, organizing, leading, controlling, and so forth.

\section{An Overview of Parent Governors' Involvement in School Governance}

Parent governors' involvement in school governance is undoubtedly one of the critical foci of education. This has become apparent with the establishment of education policies that emphasize parent involvement in school governance. Gasa [12] confirms that parent governors are an integral part of school governance. The states have a duty to improve and transform education in accordance 
with the democratic values and principles. This means that the states are duty-bound to democratize school governance so that stakeholders such as parents are accommodated. This allows them opportunity to make decisions about the way schools are governed. The most important duty of both the state and the parents is to provide the best possible education for all learners, and the best way to do this is by means of the formation of a partnership through the creation of governing bodies [3].

Kogan [17] asseverates that parent governors are part and parcel of the education system as they are part of the wider governing managerial structures through which there is a participation and representation of all social structures with an interest in education. On the same note, Macbeth [21] avers that the first duty of the parent governors is to represent the parent dimension of school governance. This notion is also emphasized by Potgieter et al. [28], as they assert that the parent governors represent the broad community spectrum such as the parents, private sector, the church, and so on. The general purpose of the parent governors is to perform management functions efficiently on behalf of the school for the benefit of the community. They are, therefore, placed in a position of trust towards the school and are expected to act in good faith to carry out all their duties and functions and to be accountable for their actions. Parent governors need to understand their duties and should be able not only to interpret education legislations and policies, but also to apply principles as contained in the legislations and policies to a particular situation.

\section{The Genesis and the Substance of the Bill of Rights and the South African Schools Act}

One of the prime examples of the constitutionalization of the South African education was the democratization of school governance. The main aim of this section therefore is to focus on legislations enacted to democratize the governance of schools.

\subsection{Bill of Rights}

The South African Constitution Act was passed in 1996 and came into operation on 4 February 1997 [26]. Chapter 2 of this Act contains the Bill of Rights in which the State guarantees the protection of individual's fundamental rights. This Bill of Rights is a cornerstone of democracy in South Africa, as it enshrines the rights of all people in the country and affirms the democratic values of human dignity, equality and freedom. Some provisions of the Bill of Rights which are of particular importance to school governance are mentioned below.

4.1.1. Equality (Section 9). This section stipulates that everyone is equal before the law and has the right to equal protection and benefit of the law. This section further on lays down that there may not be unfairly discrimination directly or indirectly against anyone on one or more grounds, including race, gender, sex, pregnancy, marital status, ethnic or social origin, color, sexual orientation, age, disability, religion, conscience, belief, culture, language and birth [16], [31].

4.1.2. Human dignity (Section 10).This section mentions that everyone has the right to have his dignity respected and protected. It is because of this section that Jones [16] submits that corporal punishment is not allowed as a person cannot be treated or punished in a cruel, inhuman or degrading manner.

4.1.3. Privacy (Section 14). This section discloses that everyone's right to privacy is guaranteed, including freedom from searches of property and person, seizure of possessions, and violation of the privacy of personal communications. Jones [16] adds that a person cannot without justifiable reason be searched nor has his property searched.

4.1.4. Freedom of religion, belief and opinion (Section 15). In this section it is stated that everyone has the right to freedom of conscience, religion, thought, belief and opinion and religious observances may be conducted at state or stateaided institutions, provided that those observances follow rules made by the appropriate public authorities, they are conducted on an equitable basis and attendance at them is free and voluntary [16].

4.1.5. The Right to Education (Section 29). This section recognizes that every person has a right to basic education and to equal access to educational institutions. This means that the state has to do all that it reasonable can to make sure that everyone receives education. Basic education is defined by the education ministry as the attainment of a General Education Certificate, on completion of 
Grade 9. The state is therefore under an obligation to provide education up to this level. Everyone has the right to receive education in the official language of his choice where this is 'reasonably practicable' [16], [31].

4.1.6. Cultural, religious and linguistic communities (Section 31). In this section it is laid down that people belonging to a cultural, religious or linguistic community may not be denied the right to enjoy their culture, practice their religion or form associations, provided that they do not contravene any other provision in the Bill of Rights [16], [31].

4.1.7. Limitation of rights (Section 36). In conclusion, in this section it is mentioned that the rights in the Bill of Rights may be limited only in terms of law of general application to the extent that the limitation is reasonable and justifiable in an open and democratic society based on human dignity, equality and freedom [16], [31].

\subsection{The South African Schools Act: Act No 84 of 1996}

The South African Schools Act (Act No. 84 of 1996) came into effect in January 1996 [7], [28]. Its essence was to transform education in South Africa away from the iniquitous policies of the past. Its main thrust was the normalization of the South African education system; the advancement of the democratic transformation of the country; the combating of racism, sexism and all forms of unfair discrimination; the promotion of the rights of learners, educators and parents and most significantly, the involvement of parents in school governance [30]

The South African Schools Act is the engine of school governance. It deals with the most important school administration policies. It is the de facto kingpin of parent governors' activities in schools, as it contains the important information on the following:

- Admission to public schools,

- Language policy of public schools,

- Freedom of conscience and religion at public schools,

- Suspension and expulsion from public school and

- Prohibition of corporal punishment (RSA, 1996a, p. 12).
In this article, the focus will be on those sections of the South African Schools Act that pertain to the school governance activities of the parent governors:

4.2.1. Admission to public schools. This section states that a public school must admit learners and serve their educational requirements without unfairly discriminating in any way. It further on stipulates that no learner may be refused admission to a public school on the grounds that his or her parent is unable to pay or has not paid the school fees determined by the governing body, does not subscribe to the mission statement of the school; or has refused to enter into a contract in terms of which the parent waives any claim for damages arising out of the education of the learner [30].

4.2.2. Language policy of public schools. In this section, it is mentioned that that the governing body of a public school must draft the language policy of the school, bearing in mind the fact that everyone has a right to receive education in an official language of his choice, where it is reasonably practically possible [26].

4.2.3. Freedom of conscience and religion at public schools. This section stipulates that religious observances may be conducted at a public school under rules issued by the governing body if such observances are conducted on an equitable basis and attendance at them by learners and members of staff is free and voluntary.

4.2.4. Suspension and expulsion from public school. In terms of this Act, a governing body may suspend a learner from school. Oosthuizen cautions that the learner must receive a lawful hearing before being suspended, and may not be suspended for more than a week. However, the period of suspension can exceed one week where it is recommended that the learner must be expelled and the governing body is awaiting the decision from the Department of Education. This section further stipulates that the expulsion of the learner may only be effected by the Department of Education , after the learner has been found guilty of serious misconduct at a fair hearing [30]. Jones [16] further on submits that the parents of the expelled learner may appeal against the decision of the HOD to the MEC. In conclusion, Naidu et al. [25] asseverate that if a learner who is subject to compulsory attendance is expelled from school, the HOD must make an alternative arrangement for his placement at another public school. 
4.2.5. Prohibition of corporal punishment. In this section, it is explained that corporal punishment in schools is prohibited. The legislature banned corporal punishment to protect learners from abuse. The section takes into consideration the importance of the child's right to dignity: Section 10 of the Constitution [28], [30].

It is therefore important to mention that parent governors that are ignorant of the legislations that have a founding impact on school governance are a liability to the school as they do not effect school governance duties.

\section{Method of Investigation}

\subsection{Research Design}

A survey to gather questionnaire-based data in a real-life setting was used in the study. The research design included the delimitation of the field of survey, the selection of respondents, the research instruments, a pilot study, the administration of the questionnaires, and the processing of data. The researcher used the cluster and simple random sampling method to select twenty rural school parent governors in each circuit in the Midlands Cluster. Since this cluster has 10 circuits, 200 parent governors were selected as respondents. This method was favoured for its simplicity, unbiased nature, and its closeness to fulfilling the major assumption of probability, namely that each element in the population stands an equal chance of being selected [18], [22].

\subsection{Research Instrument}

The questionnaire was used as research instrument. This quantitative methodology was chosen in the light of the purpose of the study, the kind of information that was required and the available resources [1], [5]. The researcher believed that this kind of survey would lead to some truths about rural school parent governors' understanding of the legislations that impact on school governance and it would provide information on whether certain generalizations presented in the literature were also true for this population.

5.2.1. Format of the questionnaire. The questionnaire was divided into four sections, with each section focusing on the aims of the study. Section 1 which dealt with the biographic and general information consisted of questions 1.1 to
1.6. This section provided the researcher with an understanding and knowledge of the respondents. Section 2 had closed questions focusing on the parent governors' knowledge of the legislations that impact on school governance. The respondents were asked to rate their responses according to the following scale: Good, Average, Poor. Section 3 had closed questions focusing on the essentiality of the parent governors' working knowledge of the legislations that impact on school governance. Questions in this section were operationalised using the following four-point scale and the respondents were asked to rate their responses as follows: Fully Agree, Agree, Disagree, Fully Disagree. Section 4 consisted of open-ended questions, wherein parent governors had to mention problems they encounter in school governance and had to suggest what could be done to improve their understanding of the legislations that impact on school governance.

5.2.2. Administration of the questionnaires. The researcher conducted a pilot study in five rural schools. These schools were part of the general population from which the sample was drawn, but not part of the sample itself. No inherent weaknesses were discovered in the questionnaire. Since the pilot study confirmed the validity and reliability of the questionnaire, there was no need to modify it. In the actual study, principals were requested to distribute the questionnaire to a parent governor whose literacy level was sufficient for him or her to complete it. It was felt that principals would be in a position to identify such parent governors.

The first sample population responses were 146 (73\%) schools. After a follow-up, 24 schools returned the completed questionnaires to make total responses of 170 (85\%) schools. That represented a satisfactory response.

5.2.3. Data processing. After all the questionnaires had been received, the important task was then to reduce the mass of data obtained to a format suitable for analysis. The respondents' responses were coded. Frequency distribution was used.

\section{Results and Discussions}

\subsection{Educational background of the rural school parent governors}

Table 1 reveals that a high proportion of parent governors (65\%) had no formal schooling. 
Table1. Educational background of rural school parent governors

\begin{tabular}{|l|l|l|}
\hline $\begin{array}{l}\text { Education } \\
\text { Qualification }\end{array}$ & $\mathbf{N}$ & $\mathbf{\%}$ \\
\hline No Formal Schooling & 110 & 65 \\
\hline Below grade 12 & 34 & 20 \\
\hline Above grade 12 & 26 & 15 \\
\hline TOTAL & $\mathbf{1 7 0}$ & $\mathbf{1 0 0}$ \\
\hline
\end{tabular}

This confirms the assertion that the education level of the population in the rural school areas is very low, with high percentages of functional illiteracy. The high illiteracy rate of rural school parent governors adversely affects school governance, as they cannot meaningfully participate in the school governance activities. This has also been noted by Monadjem [23], as she contends that parent illiteracy has been identified as one of the biggest barriers to parent involvement in school governance. The education background of parent governors prohibits them from making significant contributions in school governance matters as some decisions on policy level need trained and competent people.

\subsection{Rural school parent governors' knowledge of the Bill of Rights}

6.2.1. Rural school parent governors' knowledge of Section 9: Equality. Table 2 revealed that a high proportion of the respondents (80\%) indicated that their knowledge of Section 9: Equality was poor, whereas $20 \%$ indicated that theirs was average. That implied that most parent governors did not know how they could be involved in the implementation of this Section 9 in school governance. This section deals with the most important school governance matters such as the prohibition of unfair discrimination directly or indirectly against anyone on one or more grounds, including race, gender, sex, pregnancy, marital status, ethnic or social origin, color, sexual orientation, age, disability, religion, conscience, belief, culture, language and birth [31]. The responsibilities implied by this section pose a mammoth task for the illiterate and semi-literate parent governors and they cannot be expected to perform school governance tasks if their knowledge of this section is poor.
6.2.2. Rural school parent governors' knowledge of Section 10: Human Dignity. Again, Table 2 revealed that more than half of the respondents (80\%) indicated that their knowledge of Section 10: Human Dignity was poor, whereas $20 \%$ indicated that theirs was average. This implies that as it is the case with Section 9, most parent governors did not know how they can be involved in the implementation of this section in school governance. This section deals with school matters such as the banning of corporal punishment in schools since everyone has the right to have his dignity respected and protected [28], [31]. Once again the responsibilities implied by this section pose a difficult task for the illiterate and semiliterate parent governors.

6.2.3. Rural school parent governors' knowledge of Section 14: Privacy. Table 2, further on revealed that $60 \%$ of the respondents indicated that their knowledge of section 14 was poor, whereas $40 \%$ indicated that theirs was average. This section asserts that a person cannot without justifiable reason be searched nor has his property searched or his possession seized [28], [31].

6.2.4. Rural school parent governors' knowledge of Section 15: Freedom of religion, belief and opinion. More than half of the respondents (80\%) as indicated in Table 2, have a poor knowledge of the section 15. In this section it is stated that everyone has the right to freedom of conscience, religion, thought, belief and opinion and religious observances may be conducted at state or stateaided institutions, provided that those observances follow rules made by the appropriate public authorities, they are conducted on an equitable basis and attendance at them is free and voluntary [16].

6.2.5. Rural school parent governors' knowledge of Section 29: Education. Table 2 again revealed that a high proportion of respondents (87\%) indicated that their knowledge of Section 29 was poor, whereas $13 \%$ indicated that theirs was average. This section stipulates that every person has a right to basic education and has the right to receive education in the official language of his choice where this is 'reasonably practicable'. The section further on stipulates that the State is under an obligation to provide education up to Grade 9 [28], [31]. 
6.2.6. Rural school parent governors' knowledge of Section 31: Cultural, religious and linguistic communities. Table 2 revealed that once again more than half of the respondents (87\%) indicated that their knowledge of Section 31 was poor, whereas (13\%) indicated that theirs was average.

Table 2. Rural school parent governors’ knowledge of the Bill of Rights

\begin{tabular}{|c|c|c|c|c|c|}
\hline Items & & Good & Average & Poor & \begin{tabular}{|l|l} 
Total \\
\end{tabular} \\
\hline \multirow{2}{*}{ Section 9: Equality } & $\mathrm{N}$ & 0 & 34 & 136 & 170 \\
\hline & $\%$ & 0 & 20 & 80 & 100 \\
\hline \multirow[t]{3}{*}{ Section 10: Human Dignity } & & & & & \\
\hline & $\mathrm{N}$ & 0 & 34 & 136 & 170 \\
\hline & $\%$ & 0 & 20 & 80 & 100 \\
\hline \multirow[t]{3}{*}{ Section 14: Privacy } & & & & & \\
\hline & $\mathrm{N}$ & 0 & 68 & 102 & 170 \\
\hline & $\%$ & 0 & 40 & 60 & 100 \\
\hline \multirow{2}{*}{$\begin{array}{l}\text { Section 15: Freedom of religion, } \\
\text { belief and opinion }\end{array}$} & $\mathrm{N}$ & 12 & 22 & 136 & 170 \\
\hline & $\%$ & 7 & 13 & 80 & 100 \\
\hline \multirow[t]{3}{*}{ Section 29: Education } & & & & & \\
\hline & $\mathrm{N}$ & 0 & 22 & 148 & 170 \\
\hline & $\%$ & 0 & 13 & 87 & 100 \\
\hline \multirow{2}{*}{$\begin{array}{l}\text { Section 31: Cultural, religious } \\
\text { and linguistic communities }\end{array}$} & $\mathrm{N}$ & 0 & 22 & 148 & 170 \\
\hline & $\%$ & 0 & 13 & 87 & 100 \\
\hline \multirow[t]{2}{*}{ Section 36: Limitations of rights } & $\mathrm{N}$ & 0 & 0 & 170 & 170 \\
\hline & $\%$ & 0 & 0 & 100 & 100 \\
\hline
\end{tabular}

This is really worrying, taking into account the fact that the National Policy on Religion and Education confirms that South Africa is a multi-religious country [30]. This section observes that the freedom of religion is guaranteed and religious observances are allowed in the state or state aided institutions. This therefore means that the learners and the staff have the right to have their own religious views respected and the school needs to ensure that learners and staff with different convictions have an equal opportunity to attend religious observances according to their faith [31].

6.2.7. Rural school parent governors' knowledge of Section 36: Limitations of rights. Table 2, in conclusion revealed that all the respondents (100\%) indicated that their knowledge of Section 36 was poor. In this section, it is mentioned that the rights may be limited if the limitation is reasonable and justifiable in an open and democratic society [31].

\subsection{The rural school parent governors' knowledge of the South African Schools Act}

6.3.1. Rural school parent governors' knowledge of the school's policy on learner admission. Table 3 revealed that a majority of the respondents (80\%) indicated that their knowledge of the school admission policy is poor and $20 \%$ indicated that theirs was average.

Table 3.Rural school parent governors’ knowledge of the South African Schools Act

\begin{tabular}{|c|c|c|c|c|c|}
\hline Items & & Good & Average & \begin{tabular}{|l} 
Poor \\
\end{tabular} & Total \\
\hline \multirow{2}{*}{$\begin{array}{l}\text { School's policy on leamer } \\
\text { admission }\end{array}$} & $\mathrm{N}$ & 0 & 34 & 136 & 170 \\
\hline & $\%$ & 0 & 20 & 80 & 100 \\
\hline \multirow[t]{2}{*}{ School's Curriculum Framework } & $\mathrm{N}$ & 0 & 34 & 136 & 170 \\
\hline & $\%$ & 0 & 20 & 80 & 100 \\
\hline \multirow[t]{2}{*}{ Leamers' Code of Conduct } & $\mathrm{N}$ & 0 & 68 & 102 & 170 \\
\hline & $\%$ & 0 & 40 & 60 & 100 \\
\hline \multirow[t]{2}{*}{ School Constitution } & $\mathrm{N}$ & 0 & 68 & 102 & 170 \\
\hline & $\%$ & 0 & 40 & 60 & 100 \\
\hline \multirow[t]{2}{*}{ School's policy on language } & $\mathrm{N}$ & 0 & 34 & 136 & 170 \\
\hline & $\%$ & 0 & 20 & 80 & 100 \\
\hline \multirow[t]{2}{*}{ School's policy on religion } & $\mathrm{N}$ & 170 & 0 & 0 & 170 \\
\hline & $\%$ & 100 & 0 & 0 & 100 \\
\hline \multirow{2}{*}{$\begin{array}{l}\text { School's policy on the suspension } \\
\text { and expulsion of leamers }\end{array}$} & $\mathrm{N}$ & 0 & 48 & 122 & 170 \\
\hline & $\%$ & 0 & 28 & 72 & 100 \\
\hline
\end{tabular}

This section states that a public school must admit learners without unfairly discriminating in any way [30]. Potgieter et al. [28] point out, that in terms of the South African Schools Act, the parent governors must formulate and write the admission policy of the school. The basic mandate of the admission policy is that the school should not discriminate against learners, who must be admitted even if their parents cannot pay school fees. Tsotetsi [34] points out that the parent governors must inform parents of the learners admitted to a school of their rights and obligations, such as that education is a right not a privilege, admission tests are illegal and the payment of school fees in not compulsory.

6.3.2. Rural school parent governors' knowledge of the school's curriculum framework. It seems that the rural school parent governors in this survey have very little knowledge of the curriculum framework at the school at which they serve. As it can be seen from Table 3, the majority of the respondents (80\%) indicated that their knowledge of the school's curriculum framework is poor. This implies that although the South African Schools Act, Section 21(1) (b) demands that parent governors should set the framework for the school's curriculum and also determine its extramural curriculum and choice of subject options in terms of provincial curriculum policy, nevertheless this is not happening. Seroto [33] argues that 
allowing parents to make decisions with regard to the curriculum will deprive educators of the right of exercising their professional judgment and that such an action can result in questionable and even harmful practices. This suggests that it is only the well-informed parent governors that are qualified to collaborate with educators in terms of decisionmaking with regard to structuring a framework for the school curriculum.

6.3.3. Rural school parent governors' knowledge of the learners' code of conduct. The South African Schools Act stipulates that the school governing bodies should draw up and adopt a code of conduct for learners, which must be respected by all learners and consists of school rules, sanctions and details of procedures that must be followed during disciplinary investigations. However, as it can be seen in Table 3, the parent governors in this study do not seem equipped to do so, as more than half of the respondents $(60 \%)$ indicated that their knowledge of the learners' code of conduct was poor.

According to Potgieter et al. [28], the purpose of the code of conduct for learners is to create wellorganized and good schools where effective learning and teaching can take place, promote selfdiscipline, encourage good behavior and regulate conduct. The code of conduct consists of school rules, sanctions and details of procedures that must be followed during disciplinary investigations.

6.3.4. Rural school parent governors' knowledge of the school constitution. The South African Schools Act mandates the school governing bodies to participate in the formulation and adoption of the school constitution. However, as it can be seen in Table 3, a sizeable number of the parent governors $(60 \%)$ indicated that their knowledge of the school constitution is poor. This is a cause for concern. Tsotetsi [34] asseverates that some principals admitted to him that they used the expertise of the educators in the process of formulating the school constitution and only take the constitution to the parent governors for ratification. These principals justify their behavior by stating that most parent governors are not educated and those that are, do not have the time or necessary skills to assist in the process.

The school constitution is very important. It consists of the school's mission statement, which sets out the school's vision, describing those values that the school has decided are important. It also comprises the school ethos, which is the underlying, deep structure of the school culture, the values that animate it and collectively constitute its way of life [3]. Without the constitution, the school does not have a leg to stand on. It is a legal requirement for all schools [30].

6.3.5. Rural school parent governors' knowledge of the school's policy on language. It seems that the parent governors in this study have very little knowledge of the school language policy. As it can be seen from Table 3, a high proportion of the respondents $(80 \%)$ indicated that their knowledge of the school's language policy is poor. This section stipulates that the governing body must draft the language policy of the school bearing in mind that the Constitution stipulates that everyone has a right to receive education in an official language of his choice, where it is reasonably practically possible [7]. The factors that play a role in deciding the language policy include the majority of learners who use that language and the ability of the educators to teach that particular language.

6.3.6. Rural school parent governors' knowledge of the school's policy on religion. All parent governors in this study are knowledgeable about the religious policy at the school at which they serve. As can be seen from Table 3, they all (100\%) indicated that their knowledge of the school's policy on religion is good. South Africa is a multi-religious country with over $60 \%$ of the population claiming allegiance to Christianity. This policy, according to Tsotetsi [34] provides a framework for schools to determine their own religious policies. Parent governors lay down the rules for religious observances at the school. These observances according to Potgieter et. al. [28] are regular meetings such as school opening ceremonies, where, for example, scripture readings, prayer and religious singing take place. Freedom of religion is guaranteed in the constitution as Rossouw and Oosthuizen [28], [29] observe that religious observances may be conducted at the state or state aided institutions, provided that those observances follow rules made by the appropriate public authorities, are conducted on an equitable bases; and attendance at them is free and voluntary. The religious policy needs to ensure that learners and staff with different convictions have an equal opportunity to attend religious observances according to their faith [30]. 
6.3.7. Rural school parent governors' knowledge of the school's policy on the suspension and expulsion of learners. Table 3 , in conclusion revealed that more than half of the respondents (72\%) indicated that their knowledge of the school's policy on the suspension and expulsion of learners was poor and $28 \%$ indicated that theirs was average. In this section, it is stated that the school governing body may suspend a learner from school and the expulsion of the learner may only be effected by the Head of Department, after the learner has been found guilty of serious misconduct at a fair hearing [30]. In conclusion, one needs to note that a high proportion of the respondents in this study have a poor knowledge of the South African Schools Act. The responsibilities implied by of this Act pose a difficult task for the illiterate and semi-literate parent governors. This Act is the engine of school governance. It deals with the most important school governance matters. It is the de facto kingpin of parent governors' involvement in school governance as it contains the composition, duties, functions, rights and powers of parent governors. It is therefore ironical that the majority of parent governors have a poor knowledge of the "engine power" of school governance. Intervention in the form of training workshops is inevitable.

6.4. Essentiality of the rural school parent governors' working knowledge of the legislations that impact on the school practice

In this section, parent governors were required to determine the essentiality of their working knowledge of the legislations that impact on school governance.

6.4.1 Learners whose parents fail to pay school fees must not be admitted to school. Table 4 revealed that more than half of the respondents (59\%) indicated that they agreed with the statement that learners whose parents fail to pay school fees must not be admitted to school. This is expected of parent governors who indicated in Table 3 that their knowledge of the school admission policy is poor. The admission policy as per section 5 of the Schools Act, stipulates that the school must not discriminate against learners, who must be admitted even if their parents cannot pay school fees.
Table 4. Essentiality of the rural school parent governors' working knowledge of the legislations that impact on the school governance

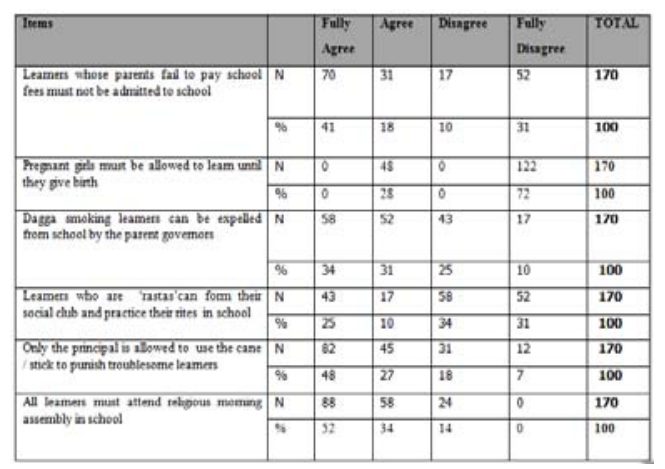

6.4.2. Pregnant girls must be allowed to learn until they give birth. Table 4 revealed that more than half of the respondents (72\%) indicated that they did not agree with the statement the pregnant girls be allowed to learn until they give birth and $28 \%$ indicated that they agreed that pregnant girls should be allowed to learn until they give birth. This section prohibits unfair discrimination directly or indirectly against anyone on one or more grounds, including pregnancy [16], [31].

6.4.3. Dagga smoking learners can be expelled from school by the parent governors. As shown in Table 4, the majority of the respondents (65\%) agreed that dagga smoking learners can be expelled from school by parent governors. The same respondents indicated in Table 3, that their knowledge of the South African Schools Act is poor. Section 9 of this Act discloses that the expulsion of the learner may only be effected by the Head of Department, after the learner has been found guilty of serious misconduct at a fair hearing [31].

6.4.4. Learners who are 'rastas'can form their social club and practice their rites in school. Table 4 further on revealed that a majority of the respondents (65\%) indicated that they did not agree with the statement that the learners who are 'rastas'can form their social club and practice their rites in school. However, Section 31 of the Bill of Rights states that people belonging to a religious or cultural community may not be denied their right to establish, join and maintain their religious or cultural associations and bodies. Furthermore, no person may be denied his right to practice his religion or culture with other members of that religious or cultural community [26]. 
6.4.5. Only the principal is allowed to use the cane / stick to punish troublesome learners. Table 4 further on revealed that a majority of the respondents $(75 \%)$ indicated that they agreed with the statement that only the principal is allowed to use the cane / stick to punish troublesome learners. This response is a cause for a worry as Section 10 of the South African Schools Act clearly states that no one is allowed to administer corporal punishment at a school to a learner [30]. The section takes into consideration the importance of the child's right to dignity: Section 10 of the Constitution [28].

6.4.6. All learners must attend religious morning assembly in school. In conclusion, Table 4 showed that a majority of the respondents (86\%) agreed that all learners must attend religious morning assembly in school. The strong support for this item indicates that parent governors do not know Section 15 of the South African Schools Act, which stipulates that the attendance of religious observances in a school is free and voluntary [4].

\subsection{Problems encountered by parent governors in school governance}

In an open-ended question, parent governors were required to mention the problems they encountered in their involvement in school governance. Their responses, ranked in the order of frequency, were as follows:

- They lack understanding of their role in school governance (87\%).

- School governance documents such, as the South African Schools Act and the Bill of Rights, are in English with no easy access to vernacular versions (78\%).

- Training is not provided in school governance matters (59\%).

- Most parent governors are farm labourers, and farm owners do not allow them to attend the school governing body meetings on work days (55\%)

- Principals dominate meetings and ignore suggestions from parent governors (47\%).

\subsection{Parent governors' suggestions on improving their understanding of the legislations that impact on school governance}

In another open -ended question, parent governors were required to make suggestions on what can be done to improve their understanding of the legislations that impact on school governance.
Their responses were ranked in the order of frequency as follows:

- The Department of Education should organize training workshops for parent governors (73\%).

- Training manuals should be written in the indigenous language (71\%)

- Schools should provide translation services for parent governors who know only the indigenous language (68\%).

- Principals should motivate parent governors to read the Bill of Rights South African Schools Act documents (65\%);

- The principal and the school have the responsibility to provide necessary documents and information available to the parent governors ( $63 \%$ );

- Schools must offer transportation to parent governors to attend training workshops (60\%)

- Parent governors must be remunerated for attending training workshops (56\%).

- Local leaders such as councilors and traditional leaders should assist in the training of parent governors in school governance legislations (51\%).

\section{Contribution to Knowledge}

The summary that follows highlights the salient issues that emerged from the study.

\subsection{The rural school parent governors' educational background}

The empirical survey revealed that a high proportion of parent governors are illiterate and semi- literate. The high illiteracy rate of parent governors negatively affects school governance, as they cannot successfully play their part in school governance activities. Monadjem [23] maintains that parent illiteracy has been identified by educators as one of the biggest barriers to parent involvement in school governance. Their educational background prohibits them from making significant contributions. The less educated the parent governors are, the more likely is that they will be reluctant to become involved in school governance matters. Monadjem explains that the parent governors' clear understanding of the legislations and policies can enhance effective school governance, and since illiteracy is a national problem, the Department of Education should vigorously and urgently initiate literacy classes for rural school parent governors. 


\subsection{The rural school parent governors' knowledge of the legislations that impact on school governance}

The study reveals that the majority of rural school parent governors have poor knowledge of the legislations that impact on school governance. The study found out that rural school parent governors did not agree with the statement the pregnant girls should be allowed to learn until they give birth, despite the fact that Section 9 of the Bill of Rights prohibits unfair discrimination directly or indirectly against anyone on one or more grounds, including race, gender, sex, pregnancy, etc [31]. The study furthermore found that the majority of the rural school parent governors were opposed to the stipulation in the Bill of Rights that people belonging to a religious community may not be denied their right to establish, join and maintain their cultural or religious associations and bodies. Furthermore, no person may be denied his right to practice his culture or religion with other members of that cultural or religious community. The study in conclusion, found that the majority of the rural school parents agreed that all learners must attend religious morning assembly in school, despite the stipulation in the South African Schools Act that the attendance of religious observances in a school is free and voluntary [16].

These findings are of great concern to school governance as the knowledge of these pieces of legislation by parent governors in South Africa has always been taken as a fait accompli, the reality is that to rural school parent governors, this still remains a wishful thinking, despite the fact that these legislations are undoubtedly the critical foci of school governance in the new democratic dispensation in the South Africa schools.

In order for schools to be effective and well managed, rural school parent governors need thorough training on the implementation of the precincts of the legislations that impact on school governance such as the Bill of Rights, South African Schools Act, the school constitution, admission policy, language policy, religious policy, code of conduct for learners, and so forth. The importance of these legislations cannot be overemphasized as they ensure that parent governors have more say in day-to-day school governance matters. It is therefore imperative that training programs for parent governors need to be initiated and that these should focus on interpreting and implementing the legislations impacting on school governance, thereby guiding parent governors in matters related to their roles and responsibilities, policy making, vision building, school management and school development [3]. Rural school parent governors need to understand the significance and the scope of their duties and they should be able to interpret these legislations and apply principles as contained in the legislations to a particular situation. It is hoped that, after training, the parent governors will come to an understanding of a democratic approach to school governance.

\section{Conclusion}

Rural school parent governors should be playing a significant role in school governance activities. They are responsible for the formulation, development and implementation and review of the school policies. This responsibility includes development of the school admission policy in consultation with the Department of Education. It also includes promotion of the best interests of the school, while striving to ensure the school's development through the provision of quality education for all learners, adoption of a school constitution and the development of the mission statement. Parent governors are therefore indispensable assets and resources in the successful formulation and implementation of school policies. According to Heystek and Louw [15], the role of parent governors in schools should be recognized as that of important decision makers. However, they lack the knowledge and the training to do so. It is essential for them to be given the necessary training, which should include the opportunity to acquire the necessary knowledge so they would be in a position to participate meaningfully in the school governance activities.

In conclusion, it should be mentioned that the parent governors themselves must be committed to attend the training sessions and convenient times for training should be chosen. Since most rural school parent governors are farm laborers, training sessions during the weekdays would be impossible. Sundays can be better suited for their training. The timing of the commencement of the training session is also very important and should take place just after parent governors have been elected and are about to start with their governance functions. Lastly, it is recommended that the training manuals should be available in vernacular language, as most parent governors can neither read nor understand English. On top of that, the facilitator should conduct the training in vernacular so that the parent governors could reap the maximum benefit from it. 


\section{References}

[1] Ary, D., Lucy, J., \& Razavieh, A. Introduction to Research in Education. (6 ${ }^{\text {th }}$. ed.). Wadsworth / Thomson Learning. Belmont,2002.

[2] Badenhorst, D. School Management: The Task and Role of the Teacher. Haum, Pretoria,1992.

[3] Catholic Institute of Education. A Handbook for the School Governing Bodies.

CIE, Johannesburg, 1997.

[4] Clarke, A. The Handbook of School Management. Macmillan, Cape Town, 2007.

[5] Cohen, L., \& Manion, L. Research Methods in Education. Rinehart and Winston. Sussex,2000.

[6] Dekker, E. Parent- Teacher Partnership. UNISA, Pretoria, 1994.

[7] Department of Education. First Steps: School Governance Starter Pack. Pretoria: Government Printers, Pretoria, 1997.

[8] Duma, M. Community Involvement in Rural schools in Pietermaritzburg Area. (Masters' Thesis, University of South Africa, 1995).

[9] Duma, M. ELCSA-SED Schools and Hostels Annual Report.ELCSA, Pietermaritzburg, 2004,

[10] Du Preez, P. Effective Education Management Series. Sundown: Heinemann, 2003.

[11] Epstein, J. School/Family/Community Partnerships: Caring for the Children We Share. Phi Delta Kappan, 76(9) 1995, pp. 701-712.

[12] Gasa, F. Understanding School Governance. USAID, Pietermaitzburg, 2000.

[13] Gerber, P. D., Nel, P. S., \& Van Dyk, P. S. (Human Resources Management. (4 ${ }^{\text {th }}$. ed.). International Publishing (Pty) Ltd, Johannesburg, 1998.

[14] Gorton, R., and Snowden, P. School Leadership and Administration: Important Concepts, Case Studies, and Simulations. WCB Brown \& Benchmark, Oxford, 1993.

[15] Heystek, J., \& Louw,E. Parental Participation in School Activities: Is it Sufficient? South African Journal of Education, 1999,19(1) pp.21-27.

[16] Jones, K. Understanding School Governance. Manual 6. Media in Education Trust., Durban,1999.

[17] Kogan, M. School Governing Bodies. Heinemann, London, 1984.
[18] Kumar, R. Research Methodology: As Step-by-Step Guide for Beginners. SAGE Publications, New Delhi, 2005.

[19] Lekalakala, M. T. Problems Experienced by School Governing Bodies in the Execution of Their Financial Management Task: A Case Study. (Masters Thesis, University of South Africa, 2006).

[20] Lotter, T.. Towards Effective School Management. Manual 12. Maskew Miller, Cape Town, 2003.

[21] Macbeth, A. Involving Parents: Effective Parents Relations. Heinemann, London 1989.

[22] McMillan, J., \& Schumacher, S. Research in Education: Evidence-Based Inquiry. Allyn \& Bacon, Boston, 2006.

[23] Monadjem, L. The Development of a Programme for Parental Involvement in Senior Primary Schools in Swaziland. (Doctoral Dissertation, University of South Africa, 2003).

[24] Mothaba, M., Potgieter, J., \& Mosoge, J. Understanding the South African Schools Act. Government Printers, Pretoria, 1997.

[25] Naidu, A., Joubert, R., Maestry, R., \& Mosoge, J. Educational Management and Leadership: A South African Perspective. Oxford University Press, Cape town, 2008.

[26] Oosthuizen, I. J. Aspects of Educational Law. Van Schaik Publishers, Pretoria, 2004.

[27] Postma, W. Co-operating with Parents. Southern Publishers, Halfway House, 1990.

[28] Potgieter, J., Mosoge, J. , \& Mothaba, M. Understanding the South African Schools Act: What Public School Governors Need to Know? Government Printers, Pretoria, 1997.

[29] Rossouw , P., \& Oosthuizen,I.. Statues for Educational Law. University of North West., Potchefstroom,2005.

[30] Republic of South Africa. South African Schools Act. : Act No 84 of 1996. Government Printers, Pretoria, 1996(a).

[31] Republic of South Africa. National Constitution. Act No 108 of 1996. Government Printers, Pretoria. 1996(b).

[32] Sayed. Y., \& Carrim, M. Democracy, Participation and Equity in Educational Governance. South African Journal of Education. 17(3), 1997, pp. 91-99. 
[33] Seroto, J. The Impact of South African Legislation (1948-2004) on Black Education in Rural Areas: A Historical Educational Perspective. (Doctoral dissertation, University of South Africa, 2004).

[34] Tsotetsi, S. The Training of School Governing Bodies in the Free State Province: An Education Management $P$ erspective .( Doctoral dissertation, University of South Africa, 2006).

[35] Unterhalter, E. Education in a Future South Africa: Policy_Issues for Transformation. Heinemann, New Hampshire, 1999.

[36] Van Schalkwyk, O. Focus on the Education Systems. Butterworths, Durban, 1998.

[37] Van Der Westhuizen, P. Effective Educational Management. Pretoria: HAUM, Pretoria: 2000. 